\title{
'A mere gutter!' The Carioca Aqueduct and water delivery in mid-nineteenth-century Rio de Janeiro
}

\author{
Alida C. Metcalf ${ }^{\star}$ (D), Sean Morey Smith ${ }^{2}$ (D) and S. Wright Kennedy ${ }^{3}$ \\ ${ }^{1}$ Department of History, MS 42, Rice University, PO Box 1892, Houston, TX 77251-1892, USA \\ ${ }^{2}$ Humanities Research Center, MS 620, Rice University, PO Box 1892, Houston, TX 77251-1892, USA \\ ${ }^{3}$ Department of History, 413 Fayerweather Hall, MC 2527, Columbia University, 1180 Amsterdam Ave., \\ New York, NY 10027, USA \\ *Corresponding author. Email: acm5@rice.edu
}

\begin{abstract}
The two key aspects of water infrastructure - engineered and human - in mid-nineteenthcentury Rio de Janeiro are the foci of this article. On the one hand, gravity flow engineering brought fresh water from the Tijuca Forest to the fountains in the city, but on the other, hundreds of slaves carried heavy jugs of water from the fountains though the streets to residences. Using the account of Thomas Ewbank (1856), georeferenced historical maps and a field study, this article first reconstructs the route of the Carioca Aqueduct, then, using the accounts of Ewbank and other travellers, turns to the delivery of water in the city by enslaved water carriers.
\end{abstract}

In 1849, the year before Brazil banned the transatlantic slave trade, the Frenchwoman Adèle Toussaint-Samson set aside a day for the famous excursion from the city of Rio de Janeiro to the Corcovado - the peak known as 'the hunchback'. Many visitors to Rio made the trip that wound up into the forest along the aqueduct that brought water to the city. According to Toussaint-Samson, parties of 15 to 20, accompanied by servants and slaves, began the ascent at 3:00 am. Touissant-Samson described the water delivered by the Carioca Aqueduct, as 'pure and sparkling' and 'so good...so limpid, so perfumed, so light...fresh and full of odors'. Thomas Ewbank undertook the same ascent in 1846 with just

\footnotetext{
${ }^{1}$ A. (Samson) Toussaint and E. Toussaint, A Parisian in Brazil (Boston, MA, 1890), 49-54, available at: http://archive.org/details/parisianinbrazil00tous, accessed 24 Jun. 2020. Many made this trip to the Corcovado and visitors often described it in later publications, frequently enhanced with illustrations. On Adèle Toussaint-Samson, see L. de Souza Maia, 'Viajantes de saias: escritoras e ideias antiescravistas numa perspectiva transnacional (Brasil, século XIX)', Revista Brasileira de História, 34 (2014), 61-81, and 'Viajantes de saias: Gênero, literatura e viagem em Adèle Toussaint-Samson e Nísia Floresta (Europa e Brasil, século XIX)', Universidade Estadual de Campinas Instituto de Filosofia e Ciências Humanas Ph.D.

(c) The Author(s), 2020. Published by Cambridge University Press. This is an Open Access article, distributed under the terms of the Creative Commons Attribution-NonCommercial-NoDerivatives licence (http://creativecommons.org/ licenses/by-nc-nd/4.0/), which permits non-commercial re-use, distribution, and reproduction in any medium, provided the original work is unaltered and is properly cited. The written permission of Cambridge University Press must be obtained for commercial re-use or in order to create a derivative work.
} 
one companion. As they waited for horses and a guide beneath the massive double arched bridge, the last segment of the aqueduct, he counted 'not less than two dozen slaves, of both sexes, [who] came to fill their barils [sic]' (barrils, water barrels) at a nearby spout. ${ }^{2}$ Ewbank was not far into his ascent when he made a surprising discovery: the aqueduct was 'a mere gutter!' These three observations capture the essence of water in Rio before 1850. Despite its monumental double arched water arcade, the aqueduct was but a small channel. It delivered fresh, good water from high in the Tijuca Forest, but in the city thousands of slaves were forced to carry water, barrel by barrel, from fountains to residences. Today, the bridge portion of the aqueduct remains a spectacular sight, but many have forgotten the gutter-sized channel that fed it and the conditions of the enslaved people who delivered the water to its final destinations.

This article focuses on the Carioca Aqueduct and locates it within the dual nature of the water infrastructure of Rio de Janeiro at this key moment in the history of Brazil. On the one hand, the water system depended on built structures such as the Carioca Aqueduct and its public fountains - and on the other on forced human labour. The aqueducts conducted, via gravity flow, water to public fountains, and from the fountains water carriers, the vast majority of whom were enslaved, delivered the water through the city's streets. Many visitors to the city commented on the aqueduct and the water carriers, but Thomas Ewbank's account is particularly valuable for he had a background in plumbing and hydraulics, ${ }^{3}$ and he made several return trips to the aqueduct. He measured its full extent, commented on its sources and acquired data on its flow, all of which appeared in the book he later published, Life in Brazil (1856). ${ }^{4}$ Although a brief part of the two-volume work, Ewbank's account of the aqueduct is significantly more detailed than other, more perfunctory, narratives about the aqueduct written by visitors to the city, such as the more romantic portrait by Adèle Toussaint-Samson. ${ }^{5}$ Using Ewbank's account as well as a nineteenth-century historical map georeferenced in a Historical Geographic Information System (HGIS), we replot the path of the Carioca Aqueduct over modern terrain. ${ }^{6}$

dissertation, 2016, www.repositorio.unicamp.br/bitstream/REPOSIP/305705/1/Maia_LudmiladeSouza_D.pdf, accessed 24 Jun. 2020.

${ }^{2}$ T. Ewbank, Life in Brazil, or, A Journal of a Visit to the Land of the Cocoa and the Palm (New York, 1856), 409, https://archive.org/details/lifeinbrazil02ewbagoog/page/n7, accessed 24 Jun. 2020.

${ }^{3}$ F. Watt, 'Ewbank, Thomas (DNB00)', Wikisource, https://en.wikisource.org/wiki/Ewbank,_Thomas_ (DNB00) accessed 4 Nov. 2019.

${ }^{4}$ A. Miguel de Frias e Navares, holding the title of Inspector Geral das Obras Públicas, signed a document on 18 May 1849; see Abastecimento d'água: aquedutos: Carioca, Laranjeiras e Maracanã, 51.1.12, 29, Arquivo Geral da Cidade do Rio de Janeiro (AGCRJ).

${ }^{5}$ Toussaint-Samson praised the water and the scenery on her ascent, which she found in great contrast to her negative views of the city, see L. de Souza Maia, 'Nísia Floresta's views of Rio de Janeiro: a city through the social criticism of a Brazilian woman writer', paper presented at the Rocky Mountain Conference of Latin American Studies, Santa Fe, NM, 2013.

${ }^{6}$ Historical Geographic Information Systems (HGIS) enable scholars to organize, visualize and analyse historical documents within a spatial framework. This ability - to put a diverse array of sources into conversation with each other based on their relationship in space - offers the potential for novel perspectives on historical topics. The HGIS used in this study brings together historical sources to visualize the built environment (e.g. roads, buildings, water infrastructure), the natural environment (e.g. marshes, waterways 
Additional historical maps, as well as a modern field study, allow us to confirm the aqueduct's historical route. Ewbank's observations of water carriers in the city, in addition to accounts of others, allow us to reconstruct the fundamental role of the enslaved water carrier within the city.

\section{Are travellers to be trusted?}

As Edward Said explained in Orientalism, historians must consider the preconceived perceptions of places and peoples carried by 'eyewitness' travellers, as well as how the genre of travel writing is deeply intertwined with power dynamics. ${ }^{7}$ For Said, travellers are fundamental to the discourse that created the idea of the Orient. A scientist, scholar, missionary, trader and soldier could think about the Orient, Said argues, 'because he could be there, or could think about it, with very little resistance on the Orient's part'. Travellers, in Said's view, were highly influenced by a vision of two worlds - the Orient - 'them' - and the West - 'us'. This limited what the traveller could see, even as he or she benefited from 'a certain freedom of intercourse [that] was always the Westerner's privilege'.

Travel literature is a complex genre, and the critical analysis of these reports has been a major theme of academic study since the publication of Orientalism. ${ }^{9}$ Travel accounts have always been important sources for scholars of Latin America because of their descriptive texts, often supplemented with engraved plates. ${ }^{10}$ In the case of Rio de Janeiro, there is an extensive literature written by travellers who landed in the city, especially after the opening of the port to trade with friendly nations, which occurred with the arrival of the Portuguese royal family and court in 1808. Accounts of life in Rio, often highly illustrated, circulated in the Atlantic World during the nineteenth century. ${ }^{11}$

and topography) and the social landscape (e.g. contemporaneous artists' renderings of scenes in the city). A version of the HGIS is publicly accessible as imagineRio, https://imaginerio.org/, accessed 24 Jun. 2020. Recent scholarship has used HGIS to understand the spatial context of topics ranging from environmental impacts of industrialization in London to the Louisiana Purchase, to the food provisioning of New York City; see J. Clifford, West Ham and the River Lea: A Social and Environmental History of London's Industrialized Marshland, 1839-1914 (Vancouver, 2017); R. Lee, 'Accounting for conquest: the price of the Louisiana Purchase of Indian country', Journal of American History, 103 (2017), 921-42; and G. Baics, Feeding Gotham: The Political Economy and Geography of Food in New York, 1790-1860 (Princeton, 2016). For more on HGIS and spatial history, see A. Knowles and A. Hillier, Placing History: How Maps, Spatial Data, and GIS Are Changing Historical Scholarship (Redlands, CA, 2008); D. Bodenhamer, J. Corrigan and T. Harris, The Spatial Humanities: GIS and the Future of Humanities Scholarship (Bloomington, 2010); and I. Gregory, D. DeBats and D. Lafreniere, The Routledge Companion to Spatial History (London and New York, 2018).

${ }^{7}$ E.W. Said, Orientalism (New York, 1978).

${ }^{8}$ Ibid., 7, 43-4.

${ }^{9}$ See R. Bridges, 'Exploration and travel outside Europe (1720-1914)', in Peter Hulme and Tim Youngs (eds.), The Cambridge Companion to Travel Writing (Cambridge, 2002), 53-69; and M.B. Campbell, 'Travel writing and its theory', in ibid., 261-78.

${ }^{10}$ For analytical approaches to travel writing as it pertains to Latin America, see M.L. Pratt, Imperial Eyes: Travel Writing and Transculturation, 2nd edn (New York, 2008); and M. Brown, 'Richard Vowell's not-so-imperial eyes: travel writing and adventure in nineteenth-century Hispanic America', Journal of Latin American Studies, 38 (2006), 95-122.

${ }^{11}$ Among the most famous are J.B. Debret, Voyage pittoresque et historique au Brésil..., 3 vols. (Paris, 1834); and J.M. Rugendas, Voyage pittoresque dans le Brésil / par Maurice Rugendas; traduit de l'allemand par M. de Golbéry,... (Paris, 1835). 
Brazilian historians have long known that travellers to Brazil fell into similar habits, reproducing the same written descriptions and repeating similar visual tropes believed to signify Brazil. ${ }^{12}$ Nineteenth-century travellers positioned themselves as superior outsiders, capable of describing the nature of 'Rio' to those who would not visit. Historians can trace citations in the travel literature, indicating that travellers to Rio often quoted those writers who came before them and expected to have their work mentioned in turn by future visitors. ${ }^{13}$ When travellers repeated descriptions and adopted characterizations of previous travellers, they reinforced stereotypes that came to be associated with the city. Traveller accounts, therefore, are held by many historians as unreliable and more revealing of the traveller than of the places visited. ${ }^{14}$

Nevertheless, the travel literature has been deemed useful by historians of Brazil because of the absence of other sources, such as diaries and personal correspondence. Travellers wrote voluminously, and they often noticed patterns of daily life. Most visitors to Rio in the nineteenth century commented on Rio's water - its source in the Tijuca Forest, its monumental arched aqueduct, its public fountains and its water carriers. Even though this commentary is influenced by European bias and racism, it is still revealing to historians seeking to reconstruct the city's water infrastructure.

The writings of travellers can be insightful when read carefully, when racial and ethnic bias is recognized and questioned and when specific descriptions are unpacked for underlying meanings. When Adèle Toussaint-Samson wrote about the group's stop at Dois Irmãos (Two Brothers), a place along the aqueduct in Santa Teresa, her description of water is illuminating. Toussant-Samson wrote 'the negroes filled the canecas (tin cans) with pure and sparkling water, of which Europeans can have no idea'. In this simple sentence Toussaint-Samson comments on the poor quality of water in European cities of the time and suggests the superiority of the water in Rio. At the same time, she alludes to the fundamental role of slaves in the city by noting that slaves served water to her and to others in her party. ${ }^{15}$ Although on the surface this would seem to be a simple act - offering a drink of water - in fact Toussaint-Samson captures in miniature what happened all across the city: in Rio, slaves delivered the water. The same association is made by the Reverend Robert Walsh, who was in Rio in 1828-29 as chaplain to the British Ambassador Extraordinary Viscount Strangford. Walsh's observation is made with blatant and disturbing racism. Walsh writes that Rio's water 'as it is at present conveyed by negroes, is singularly offensive'. For Walsh, the water was 'defiled' by the black water carriers who delivered water through Rio's streets. 'It is impregnated with the perspiration that streams from their naked bodies', he states, 'and they constantly thrust their hands and arms in the bottom of their cans for any purpose; and the water there has always a foul look and bad odour.' Walsh's comments reveal explicitly his view that black water carriers polluted the

\footnotetext{
${ }^{12}$ L. de L. Martins, O Rio de Janeiro dos viagantes: o olhar britânico, 1800-1850 (Rio de Janeiro, 2001).

${ }^{13}$ Said emphasizes how Orientalists cited each other, and a similar pattern can be seen in the travel accounts for Rio. For example, sea captains often repeated Cook's observation on the water in Rio.

${ }^{14}$ M.G. Aune, 'Early modern European travel writing after Orientalism', Journal for Early Modern Cultural Studies, 5 (2005), 121 and passim.

${ }^{15}$ Toussaint and Toussaint, Parisian in Brazil, 52.
} 
'pure, limpid, and cold' water of the Carioca Aqueduct. His racist comments also suggest his underlying fear of the power of the black water carrier, as well as the city's dependence on slaves for basic needs. ${ }^{16}$

Is Ewbank's account to be trusted? He claims that the Office of Public Works in Rio had no historical documents describing the building of the Carioca Aqueduct, and that he received permission from a 'Colonel Frias, distinguished superintendent of the Public Works' to study the aqueduct himself. ${ }^{17}$ On the surface, this seems like an exaggerated claim, and one loaded with the bias of an outside observer. However, key elements of this claim can be verified. Archival research in Rio uncovered an A. Miguel de Frias e Navares, holding the title of Inspector Geral das Obras Públicas (Inspector General of Public Works), who signed a document on 18 May 1849, making it likely that Ewbank did at least know of the leadership in the Office of Public Works in Rio. ${ }^{18}$ Similarly, extensive searches for documents about the construction of the Carioca Aqueduct have found documents only in the Archivo Historico Ultramarino (Overseas Historical Archive) in Lisbon. ${ }^{19}$ Only documents pertaining to maintenance of the aqueduct and its fountains in the nineteenth century are to be found in Rio, largely in the Arquivo Geral da Cidade do Rio de Janeiro. This suggests that the Office of Public Works in Rio likely did not have in its possession any of the historical documents on the construction of the Carioca Aqueduct. The documentation the office preserved would have pertained to works completed in the nineteenth century, suggesting that Ewbank's claim is substantially true.

\section{How unique is Rio's water system?}

Despite its name, Rio de Janeiro does not lie on a river. This makes it different from most cities that have grown organically alongside rivers that supply a continuous source of fresh water. Yet, like other colonial cities, Rio was founded to serve the colonial enterprise. The Ordinances of King Phillip II (1573) established principles for the creation of cities in the Spanish American colonies, and one of the first was that the site for a city must have access to good water. ${ }^{20}$ The Portuguese organized their colonial settlements differently, given that their initial focus was on maritime trade rather than defending huge territories. Early Portuguese colonial settlements

\footnotetext{
${ }^{16} \mathrm{R}$. Walsh, Notices of Brazil in 1828 and 1829 (London, 1830), 507-8, 496.

${ }^{17}$ A. Miguel de Frias e Navares, holding the title of Inspector Geral das Obras Públicas, signed a document on 18 May 1849; see Abastecimento d'água: aquedutos: Carioca, Laranjeiras e Maracanã, 51.1.12, 29, AGCRJ, making it likely that Ewbank did at least know of the superintendant of the Office of Public Works in Rio. Similarly, the documents that describe the construction of the Carioca Aqueduct are today to be found in the Archivo Histórico Ultramarino in Lisbon. These may be found in the Projeto Resgate: Biblioteca Luso Brasileira, available through the Biblioteca Nacional Digital Brasil. Documents pertaining to maintenance of the aqueduct and its fountains in the nineteenth century are to be found in Rio, in the AGCRJ.

${ }^{18}$ Abastecimento d'água: aquedutos: Carioca, Laranjeiras e Maracanã, 51.1.12, 29, AGCRJ.

${ }^{19}$ These are available in Projeto Resgate - Rio de Janeiro Avulsos (1614-1830), Biblioteca Luso-Brasileira, http://resgate.bn.br/docreader/docmulti.aspx?bib=resgate\&pagfis=, accessed 24 Jun. 2020.

${ }^{20}$ On the Spanish colonial urban planning principles, see J. Kinsbruner, The Colonial Spanish-American City: Urban Life in the Age of Atlantic Capitalism (Austin, 2005), 1-12, 23-32; and D. Stanislawski, 'Early Spanish town planning in the New World', Geographical Review, 37(1947), 94-105.
} 
resembled fortified commercial entrepôts. Fifteenth-century examples, such as Arguim or São Jorge da Mina in West Africa, were designed for few residents, all of whom served as employees of the crown. ${ }^{21}$ Rio de Janeiro fell between the Portuguese and the Spanish patterns: it served as a fortified site to protect trade, but it also supported the missionary outreach of the Jesuits and the first settlers who were granted lands for cultivation. Rio soon developed an upper/lower city layout not uncommon in the Portuguese colonial world. ${ }^{22}$ The top of the hill known as the Morro do Castelo (Castle Hill) served as the city centre, while the beachfront functioned on behalf of trade. However, as the city began to descend gradually from the Morro do Castelo, it expanded along the lower beachfront that fronted the harbour where there was no easy access to fresh water. Whereas wells could be sunk on the Morro do Castelo, the lower city spread over reclaimed swamps and lagoons making the digging of decent wells impossible. In the early eighteenth century, after considerable investment by the crown, the aqueduct began to deliver water. In 1750, the monumental double arched water bridge connected Morro de Santa Teresa (Santa Teresa Hill) to Morro do Santo António (Santo Antonio Hill) and brought water to the south-western edge of the city. At that time, the city had two public fountains. More fountains were built in the second half of the eighteenth century, but when the prince regent, ailing queen and the rest of the royal family and court arrived in 1808, Rio still relied on the Carioca Aqueduct. Water carriers, the majority of whom were enslaved peoples of African descent, filled water vessels and carried the water through the city streets. ${ }^{23}$

Rio was not unique in its dependence on an aqueduct. Other cities in colonial Latin America used aqueducts, the most famous being Mexico City. Beginning in Aztec times, Tenochtitlan relied on an aqueduct to bring water from Chapultepec, and following the conquest, life in Mexico City continued to be contingent on an aqueduct to deliver fresh water. By the end of the eighteenth century, a second major aqueduct had been built, and the city had 20 public fountains. Public buildings, such as hospitals, had their own private access to water from the aqueducts. ${ }^{24}$ The city of Havana, which like Rio was a fortified port city, had an aqueduct that was finished by the end of the sixteenth century. The aqueduct brought water from the Almendares River west of the city. As in Rio, Havana's aqueduct fed public fountains that were open to all, and as in Rio, Havana suffered from periodic water shortages. ${ }^{25}$ Other capital cities, such as Buenos Aires, were located on rivers, which provided direct access to water to residents. In Buenos Aires, the ribera - riverfront - was by law and custom a commons, and residents

\footnotetext{
${ }^{21}$ R.C. Smith, 'Colonial towns of Spanish and Portuguese America', Journal of the Society of Architectural Historians, 14 (1955), 3-12; D. Birmingham, 'The Regimento da Mina', Transactions of the Historical Society of Ghana, 11 (1970), 1-7.

${ }^{22}$ Smith, 'Colonial towns'.

${ }^{23}$ A.C. Metcalf, 'Planning for water in colonial Rio de Janeiro', unpublished manuscript.

${ }^{24}$ S.B. Glasco, Constructing Mexico City Colonial Conflicts over Culture, Space, and Authority (New York, 2010), 77-90; B.E. Mundy, The Death of Aztec Tenochtitlan, the Life of Mexico City (Austin, 2015), 190208.

${ }^{25}$ P.B. Niell, 'Rhetorics of place and empire in the fountain sculpture of 1830s Havana', The Art Bulletin, 95 (2013), 445; M.M. Portuondo, 'Una Obra maestra: el acueducto Albear de La Habana (review)', Technology and Culture, 46 (2005), 203-5.
} 
bathed, fished, did laundry and collected water for home use directly from the river. Water sellers generally drew water above the city, while laundresses washed directly on the banks along the city. ${ }^{26}$

Colonial patterns continued in the nineteenth century, at least until 1850. In nineteenth-century Mexico City, neighbourhoods outside of the city centre did not have easy access to water. The same was true as Rio began to grow rapidly in the nineteenth century. Mexico City, like Rio, relied on water carriers. But unlike Rio, the water carriers in Mexico City were free, and they were part of the working class of the city, even if on its lowest rungs. Because of the inaccessibility of fountains in the distant neighbourhoods, water sellers in Mexico City could charge high sums for their water, which made water expensive for the poor who lived outside of the city centre. ${ }^{27}$ A huge new aqueduct was planned for Havana when at midcentury the limitations of its water supply were recognized by the Spanish crown. Other investments, such as in fountains, plazas and alamedas, suggest that Spain saw the benefit of spending lavishly on public works and public spaces that benefited the local elites in its remaining colonies. ${ }^{28}$

The elements of Rio's water system were not in and of themselves unique, for other Latin American cities had aqueducts, public fountains and water carriers. What does seem to be distinguishing is the excellent but limited supply of water that the city could expect and the large number of slaves forced to carry it. As the city began to grow rapidly in the nineteenth century, a second aqueduct had to be built, and more fountains had to be opened. But there was no replacement for the slaves who continued to deliver water even when the first independent water sellers began to operate. The degree to which the city relied on urban slavery to complete the water cycle does seem to be a distinctive feature of Rio de Janeiro. This fact makes the ending of the transatlantic slave trade in 1850 a significant moment in the history of the city, for after 1850 it would become less likely that the city could continue to depend on slaves to deliver its water.

\section{The Carioca Aqueduct}

Named for the Carioca River that rose at the base of the Corcovado Peak, the construction of the aqueduct began as early as 1659 . Rio's first public fountain, placed in the square at the back of the city below the monastery of Santo António, began to flow in 1723. The square soon became known as the Largo da Carioca (Carioca Square), named for the fountain and its water source. The fountain itself was designed in Lisbon; its stones cut and shipped from Portugal. The aqueduct became monumentally visible when the double arched arcade - known today as the Arcos da Carioca (Carioca Arches) or the Arcos da Lapa (Lapa Arches) - was finished by the viceroy in 1750, replacing an older part of the original aqueduct. At this time, a second major fountain, also designed and shipped from Lisbon, delivered water to

\footnotetext{
${ }^{26}$ B. Bockelman, 'Along the waterfront: Alejandro Malaspina, Fernando Brambila, and the invention of the Buenos Aires cityscape, 1789-1809', Journal of Latin American Geography, 11 (2012), 72, 76.

${ }^{27}$ Glasco, Constructing Mexico City Colonial Conflicts, 77-90; M.E. Francois, A Culture of Everyday Credit: Housekeeping, Pawnbroking, and Governance in Mexico City, 1750-1920 (Lincoln, NB, 2006), 91, 92.

${ }^{28}$ L.A. Pérez, Intimations of Modernity: Civil Culture in Nineteenth-Century Cuba (Chapel Hill, 2017), 32-8, 78; Niell, 'Rhetorics of place and empire', 459-60.
} 
the main square that opened on one side to the Guanabara Bay. Fed by the Carioca Aqueduct, the water came to the new fountain from the Carioca fountain via underground pipes. This fountain was replaced in 1775 when the square was modified, but this time the new fountain was designed and built in Rio. Moved from the centre of the square to the waterfront, the second fountain on the seawall gave easier access to ships seeking to replenish their water casks. Other fountains were built in the late eighteenth century, bringing the total number of public fountains in the city to nine when the Portuguese royal court, fleeing Napoleon, landed in $1808{ }^{29}$

By the time Thomas Ewbank arrived in Rio in 1846, a second aqueduct - the Maracanã - had been constructed, as well as several new fountains. ${ }^{30}$ His account focuses only on the original aqueduct - the Carioca. Nevertheless, Ewbank's account stands out from many other observations made about the Carioca Aqueduct $^{31}$ because he shows how it worked and why it delivered, except in times of heavy rains, uncontaminated water directly from the Tijuca Forest into the city. Several illustrations accompany the text, and these appear to be based on sketches by Ewbank that were later engraved for the publication by Lossing and Barritt. ${ }^{32}$ The text and sketches work together. For example, before beginning the first ascent, while waiting for their horses and guide under the water bridge arcade on the Rua dos Arcos, Ewbank describes the scene in words and includes an illustration (Figure 1):

At our right towered a part of the aqueduct arches; facing us arose the dead wall of the Teresa Convent garden, and...[p]rojecting from the wall are spouts to supply the vicinity with water. Not less than two dozen slaves, of both sexes, came to fill their barils [sic] during the few minutes we waited, several of whom carried the liquid high up the hill down which it comes. ${ }^{33}$

In the illustration, Ewbank positions each of the features of water delivery that he describes in the text. The double arched arcade is massive and dominates the image. The Rua dos Arcos (Street of the Arches) passes beneath, and on the street can be

\footnotetext{
${ }^{29}$ Metcalf, 'Planning for water'.

${ }^{30}$ For the Maracanã Aqueduct, see A.C. Metcalf and S.M. Smith, 'Mapping the Maracanã Aqueduct: reconstructing the route of Rio de Janeiro's second major aqueduct', e-Perimetron, 13 (2018), 1-22, http://www.e-perimetron.org/Vol_13_1/Metcalf_Smith.pdf, accessed 24 Jun. 2020.

${ }^{31}$ British visitors penned many accounts of the aqueduct, especially sea captains who reprovisioned their ships with water and food in Rio. These accounts are useful but do not describe the aqueduct in detail. For example, Cook wrote in his journal in 1768: 'The city of Rio de Janeiro is supplied with Water from 2 Different parts of the Adjacent Mountains. That which comes from the Southward is Convey'd a Cross a Deep Valley by an Acquiduct, which Consists of a great Number of Arches placed in 2 Rows, one upon the other; from thence in pipes to a fountain which stands in the Middle of the Square before the Vice-Roy's Palace', in W.J.L. Warton (ed.), Captain Cook's Journal during the First Voyage Round the World, Made in H.M. Bark 'Endeavor' 1768-71 (London, 1893), Project Gutenberg, www.gutenberg.org/ files/8106/8106-h/8106-h.htm, accessed 24 Jun. 2020.

${ }^{32}$ Benson J. Lossing and William Barritt had an engraving company in New York, dating from 1838 and still in business in 1862; see 'Oldest wood engraving establishment in New York', Broadside, sm \# Am 1862 Lossing 14874.Q (Zinman), Library Company of Philadelphia, https://digital.librarycompany.org/islandora/ object/Islandora\%3A6298, accessed 24 Jun. 2020.

${ }^{33}$ Ewbank, Life in Brazil, 409.
} 


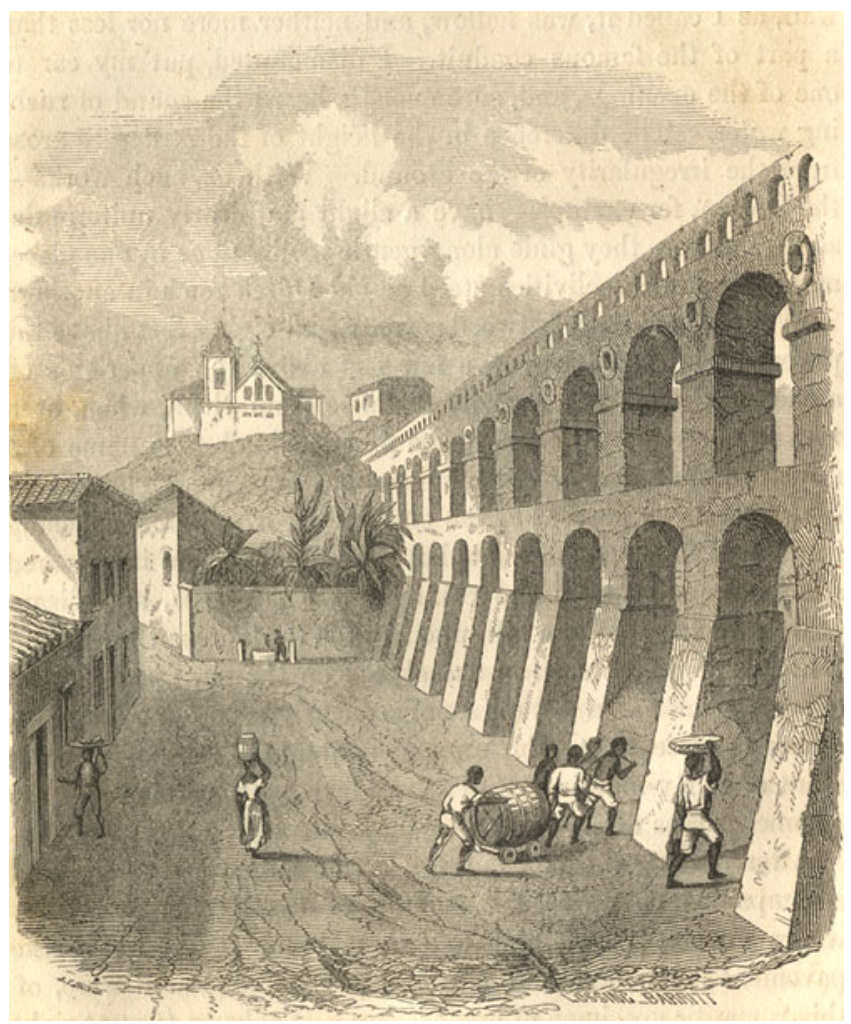

Figure 1. Double arched water bridge with water carriers Source: 'Arcos Street', in Ewbank, Life in Brazil, 409.

seen a huge water cask set on a small flat platform with wheels, pulled by slaves. The Santa Teresa convent rises on a hill, and below it, at street level, is a wall from which extends a pipe, with a stone basin beneath. A slave woman appears to be filling a water vessel, and another slave woman is shown on the street, with a water vessel on her head. This vessel is the barril which elsewhere Ewbank will illustrate and also remark that it holds about seven gallons, giving it a weight of at least 70 pounds (31.75 kilogrammes). ${ }^{34}$

Ewbank was not far into his observations of the Carioca Aqueduct when he made a surprising analogy: the long aqueduct with its magnificent double arched water bridge was 'a mere gutter!' By this, he did not mean that the water was dirty; rather, that the size of the channel was small, similar in size to that of a rain gutter. This realization came after Ewbank left the water bridge arcade during his ascent of the Morro de Santa Teresa. Ewbank noticed 'a stone fence or stuccoed

\footnotetext{
${ }^{34}$ Here we use the British standard: the imperial gallon, rather than the Queen Anne's gallon, then used in the US. A standard imperial gallon of water weighs 10 pounds (vs. the 8.34 pounds of the Queen Anne's gallon); see 'Imperial units', Britannica Academic, Encyclopædia Britannica, 20 Sep. 2019. academic-eb-com.ezproxy.rice.edu/levels/collegiate/article/Imperial-units/16522, accessed 4 Jan. 2020.
} 


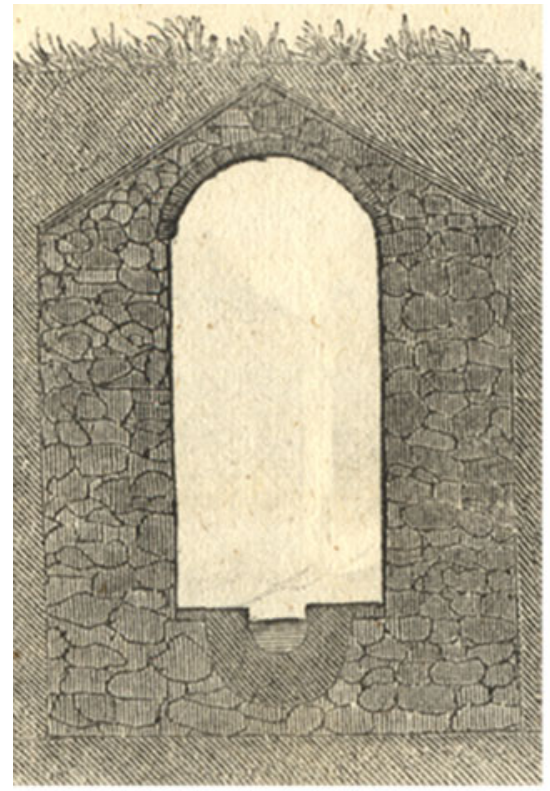

A. 'Section of the Carioco [sic] Aqueduct'

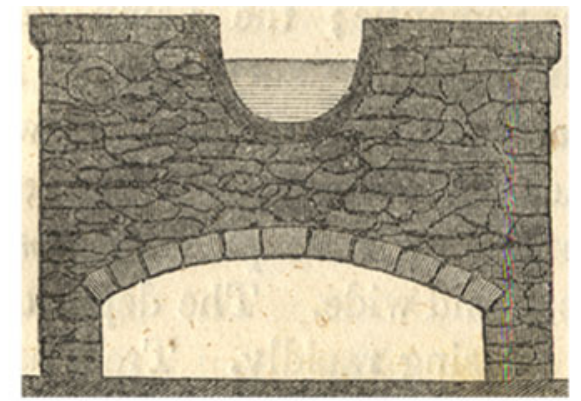

B. 'Section of the Paineiras Feeder'

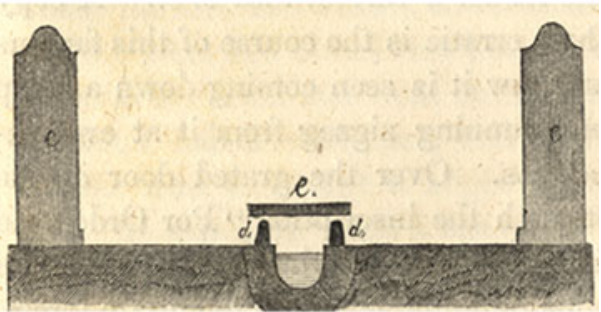

C. Section of the double arched Water Arcade

Figure 2. Ewbank's cross sections of the Carioca Aqueduct Source: Ewbank, Life in Brazil, 412, 425, 427.

wall, varying from five to eight feet in height' in places 'capped with peaked ridges'. Initially, he took it to be a support, to prevent the mountainside from sliding down and blocking the steep path that led up to the convent. The guide told him, however, that the wall was hollow and part of the aqueduct. Ewbank writes, 'I dismounted, put my ear to one of the openings, and, sure enough, heard the sound of rushing water.' Assuming that the water filled the space, he asked how high up the 21-inch thick walls the water reached. The guide replied that the water never reached the walls. Rather, the water remained in a small, 'semi-circular channel, cut in granite slabs laid at the bottom'. Higher up, Ewbank entered this hollow wall, which he described as tall enough for him to stand erect and almost wide enough for two people to walk abreast. He estimated the size of the water channel as at most only $9 \frac{1}{2}$ inches deep by 9 inches wide. ${ }^{35}$

Ewbank sketched a cross section of the aqueduct, and for this illustration, he chose a place where, to preserve the downward flow, the aqueduct had been positioned underground. As can be seen in Ewbank's cross section of the inside of the aqueduct (Figure 2A), the entire aqueduct is covered with earth. But more important is the inside, and here Ewbank carefully rendered thick walls, the roof with a steep pitch on each side, and the granite slab at the bottom that channelled the water.

Ewbank noticed that central to the working of the aqueduct were the caixas (water boxes or holding tanks) that had been built in key locations. Some of the

\footnotetext{
${ }^{35}$ Ewbank, Life in Brazil, 411-12.
} 

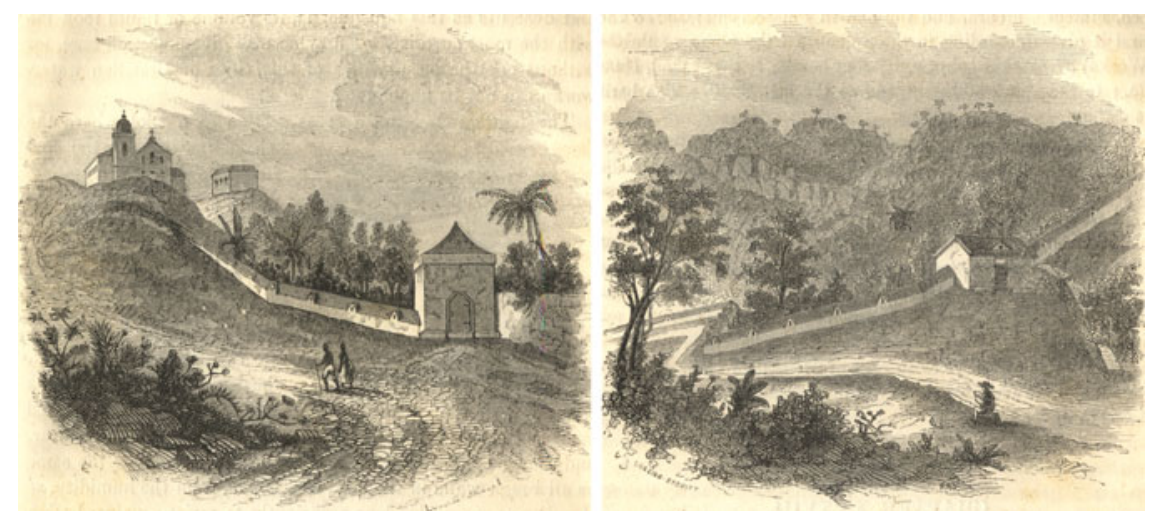

Figure 3. Aqueduct and caixas

Sources: Left: 'Aqueduct and caixa', in Ewbank, Life in Brazil, 411. Right: 'Carioco [sic] Aqueduct', in Ewbank, Life in Brazil, 429.

caixas had more than one source of water, such as the caixa in Santa Teresa that had two stretches of the aqueduct leading to it. Ewbank made two sketches that show stretches of the covered aqueduct reaching and exiting from these water boxes. In one (Figure 3, left) the Santa Teresa convent appears high on a hill, and the tall, covered aqueduct descends to a caixa with a peaked roof. In the second illustration, the aqueduct descends from the hills to a house-like structure, which served as the caixa, and from it two separate stretches of the aqueduct emerge. Note that Ewbank posed himself in this illustration, sketching the waterworks (Figure 3, right).

The course of the aqueduct, Ewbank observed, consisted of straight stretches that changed directions every few feet. Periodically, Ewbank found locked gates through which water could be extracted from small basins; these openings had been constructed to allow those living on the chácaras (small farms or villas) nearby to obtain water. Ewbank entered through one of these unlocked gates - 4 feet square - and walked along the aqueduct. Inside, he noted 'sufficient light' supplied by $10 \times 7$-inch openings every 15 or 20 feet. He writes, 'the little stream gurgled as it rushed between my feet, and boiled and foamed in the basin at the grating. ${ }^{36}$

Above the Santa Teresa convent, a 'narrow and grassy road' followed the aqueduct, 'seldom less than five feet high'. On one side, Ewbank writes, is 'a forest precipice'; on the other, the aqueduct, sometimes with a 'velvet foot-path' along its roof. Eventually, they reached 'Mai de Agua' (Mãe d'Água) which Ewbank correctly translates as 'the Mother of Waters'. He writes that it consisted of 'a rude basin, some thirty feet by twelve, formed in the rock, and having a rural roof over it'. Ewbank explains that although the water is 15 inches deep, it 'does not spring up within it, but comes down, a miniature cataract, from projecting precipices'. Various springs fed it, the most important being the Carioca River. In addition, Ewbank names four other springs 'whose trickling treasures are thus gathered together. Each is named after the mountain from whose sides, or the cavern out

\footnotetext{
${ }^{36}$ Ibid., 412-13.
} 


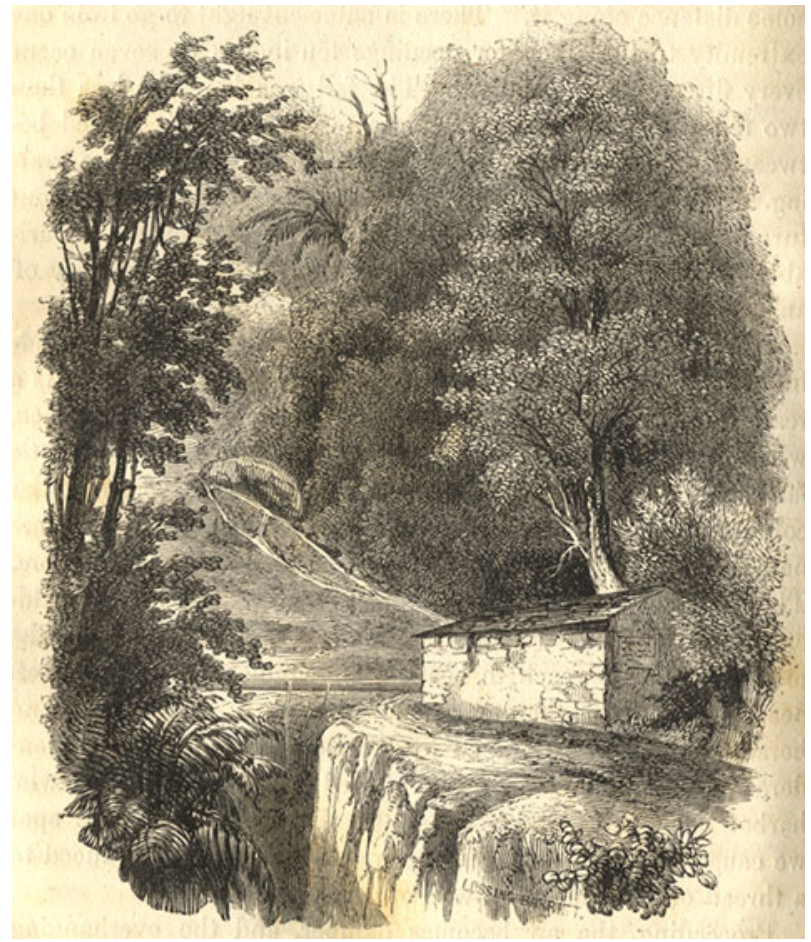

Figure 4. Mother of Waters (Mãe d'Água)

Source: 'The Mother of Waters', in Ewbank, Life in Brazil, 415.

of which, it gushes.' All conveyed water through open tiles. Two more springs were the Silvestre and the Paineiras. In rainy weather, he notes that the springs become torrents, and to protect the aqueduct below, a system was in place to allow the excess water to escape over the edge into 'a yawning gulf. ${ }^{37}$ Ewbank's illustration (Figure 4) shows the house-like structure that covered the 'rude basin', the springs leading to it, a pipe leading from it and the lush vegetation of the tropical Atlantic forest that surrounded it.

On one side of the structure, next to where the reservoir joined the aqueduct, Ewbank described a marble tablet inscribed with the name of the governor and captain general of Rio de Janeiro, Gomes Freire de Andrade, as well as the date: $1744 .^{38}$ This plaque can be seen in Ewbank's sketch; it is visible as a rectangular box on the back wall, in the lower right of the illustration (see Figure 4). The Mother of Waters sat below the Corcovado Peak, and after he left it to summit, Ewbank describes the

\footnotetext{
${ }^{37}$ Ibid., 415. Ewbank names the springs, apart from the Carioca, as: the Corcovado, das Velhas, Serra, Lagurnal and Regilio. The Carioca springs refer to the headwaters of the Carioca River, which flowed down into the southern part of the city to Larangeiras and there emptied into the Guanabara Bay at Flamengo beach.

${ }^{38}$ Ewbank, Life in Brazil, 414-15.
} 
Table 1. Gravity flow, Carioca Aqueduct

\begin{tabular}{|c|c|c|}
\hline Distances & Feet & Fall in feet \\
\hline Feeders above Mãe d’Agua & 14,166 & Unknown \\
\hline Santa Teresa to Mãe d’Agua & 18,128 & 520 \\
\hline Santa Teresa to the last caixa above the water bridge & 1,290 & 230 \\
\hline Water bridge 'Arcos da Carioca' & 833 & 5 \\
\hline Unidentified segment $^{a}$ & 54 & \\
\hline Total approximate length and fall & 34,471 & $\sim 1000$ \\
\hline
\end{tabular}

${ }^{a}$ Ewbank has two separate sets of figures that do not quite line up. In the text (427) he cites the numbers presented in Table 1, but at another point, in more tabular form (428), he lists the length from the Mother of Waters to Santo Antonio Hill as 20,305 feet, and the total length of the feeders as 14,166 feet, which adds up to 34,471 feet. Either there is a segment he did not describe in the text that he includes in the measurements for the total or there is an error in the printing.

Source: Numbers reported by Ewbank, Life in Brazil, 427-8.

Paineiras feeder, the longest and most expensive to build. This feeder, which collected the water of the Paineiras stream, flowed mainly through open tiles to Mãe d'Água except in a few places where a small, raised conduit had been built on the face of the mountain. Ewbank describes the conduit as slightly more than 3 feet high and 3 feet wide, and notes that it was built over arches with a 3 -foot span. The tiles that carried the water were imbedded in the top, 9 inches deep and 12 inches wide (see above, Figure 2B).

As for the famous Arcos da Carioca, the monumental double arched water bridge arcade, Ewbank learned that its water channel was identical in size to that of the aqueduct above Santa Teresa or to the Paineiras Feeder. Ewbank later measured the water bridge at 833 feet long; and he counted 40 or 42 arches. In his illustration, his labels identify each part: $c=$ the two parapet walls; $d=$ the two 6 -inch stucco walls; $e=$ the loose boards covering water channel) (see above, Figure 2C). The distance between the two parapet walls $(c)$, measured 9 feet from outside to outside, but the waterway itself was created from granite stone or clay tiles, 9 inches across, and 9 inches deep. The low wall, 6 inches above the waterway $(d)$, prevented the channel from overflowing and served as the support for the loose boards $(e)$ that covered the water channel.

On subsequent visits, Ewbank measured the length of the aqueduct above Santa Teresa segment by segment, using a pole, a straight-edge and a level. He reported that there was great variation in the amount of the fall, but no stretch delivered water at less than a fall of 4 inches in 15 feet. $^{39}$ From the Mother of Waters to Santa Teresa, the fall was over 500 feet, from Santa Teresa to the last caixa before the water bridge, the fall was 1 foot in 5 feet for a total of 230 feet, while across the 833 foot-long water bridge, the fall was 5 feet (see Table 1). The entire length of the aqueduct had been measured by the Office of Public Works, and Ewbank gives their figures as 4,543 braças. $^{40}$ Converting braças into feet, and adding in the total fall, he gives the length and fall of the Carioca Aqueduct as 34,471 feet with a fall of 1,000 feet (see Table 1 ).

\footnotetext{
${ }^{39}$ Ibid., 410.

${ }^{40}$ The braça is generally accepted as equal to 7.3 feet.
} 


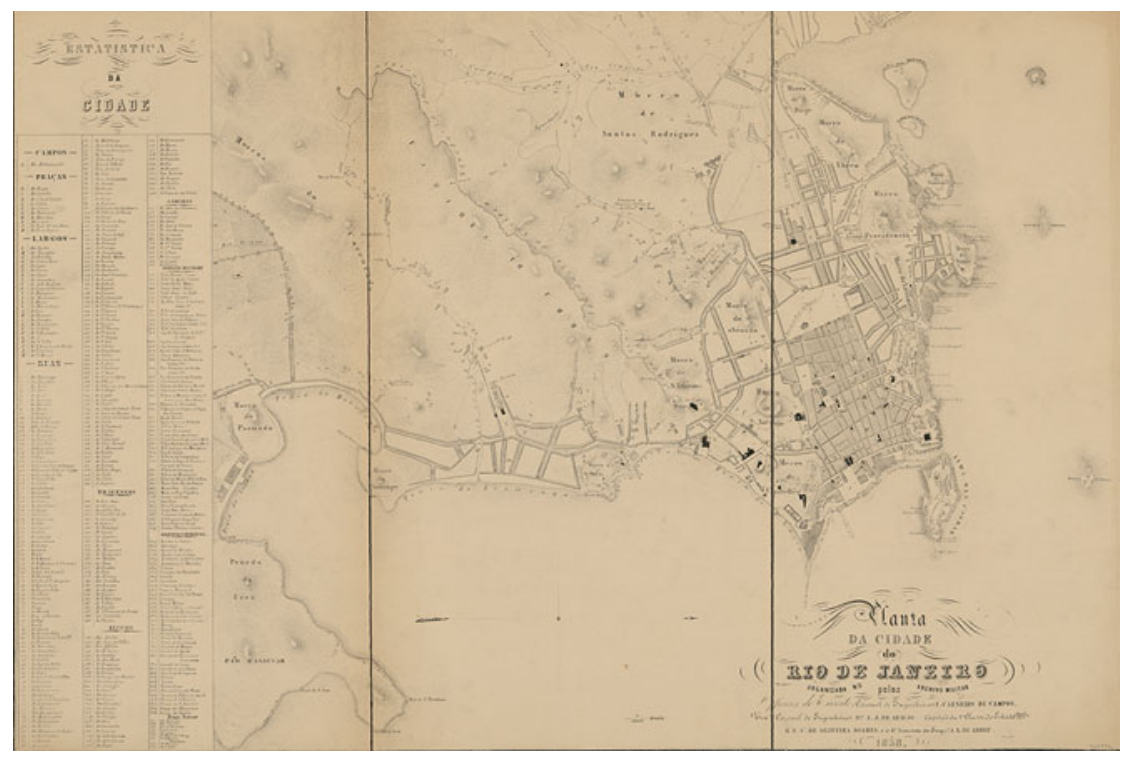

Figure 5. Map of Rio de Janeiro, 1858

Source: Carneiro de Campos et al., Planta da Cidade do Rio de Janeiro, 1858. Geography and Map Division, Library of Congress, http://hdl.loc.gov/loc.gmd/g5404r.ct003652, available in imagineRio 1858.

On the map titled Planta da Cidade do Rio de Janeiro (1858) (see Figure 5), Brazilian military engineers drew the route of the Carioca Aqueduct, which began in the forest well beyond the city centre. ${ }^{41}$ The aqueduct appears in segments, as Ewbank describes. Ewbank measured 214 stretches of the aqueduct between the Mãe d'Água to Santa Teresa Hill, describing them as all straight lines; each segment joined the next at an angle 'more or less obtuse, seldom acute'. ${ }^{42}$ Each segment had a different length, most under 100 feet, and a few smaller than 30. The map reproduces Ewbank's basic point: the aqueduct consisted of segments of different sizes that were joined together at angles of varying degree. The 1858 map, however, shows only about 160 segments. ${ }^{43}$ It is difficult to pinpoint how Ewbank or the military engineers differentiated between each stretch.

Advances in computer technology allow us to re-examine the differences between Ewbank's account and the historical map of Rio de Janeiro that presents the path of the aqueduct. When a historical map is digitized and georeferenced, tools in GIS help to approximate the location of the aqueduct over modern ter-

\footnotetext{
${ }^{41}$ F. Carneiro de Campos et al., Planta da Cidade do Rio de Janeiro (Rio de Janeiro, 1858), available through the Geography and Map Division, Library of Congress, http://hdl.loc.gov/loc.gmd/g5404r. ct003652, accessed 24 Jun. 2020, also available georeferenced in imagineRio 1858, https://imaginerio.org, accessed 24 Jun. 2020.

${ }^{42}$ Ewbank, Life in Brazil, 427.

${ }^{43}$ Many of the segments are clearly discernible, but some lack definition and blend together. After multiple counts, we feel confident the map shows between 155 and 167 segments.
} 


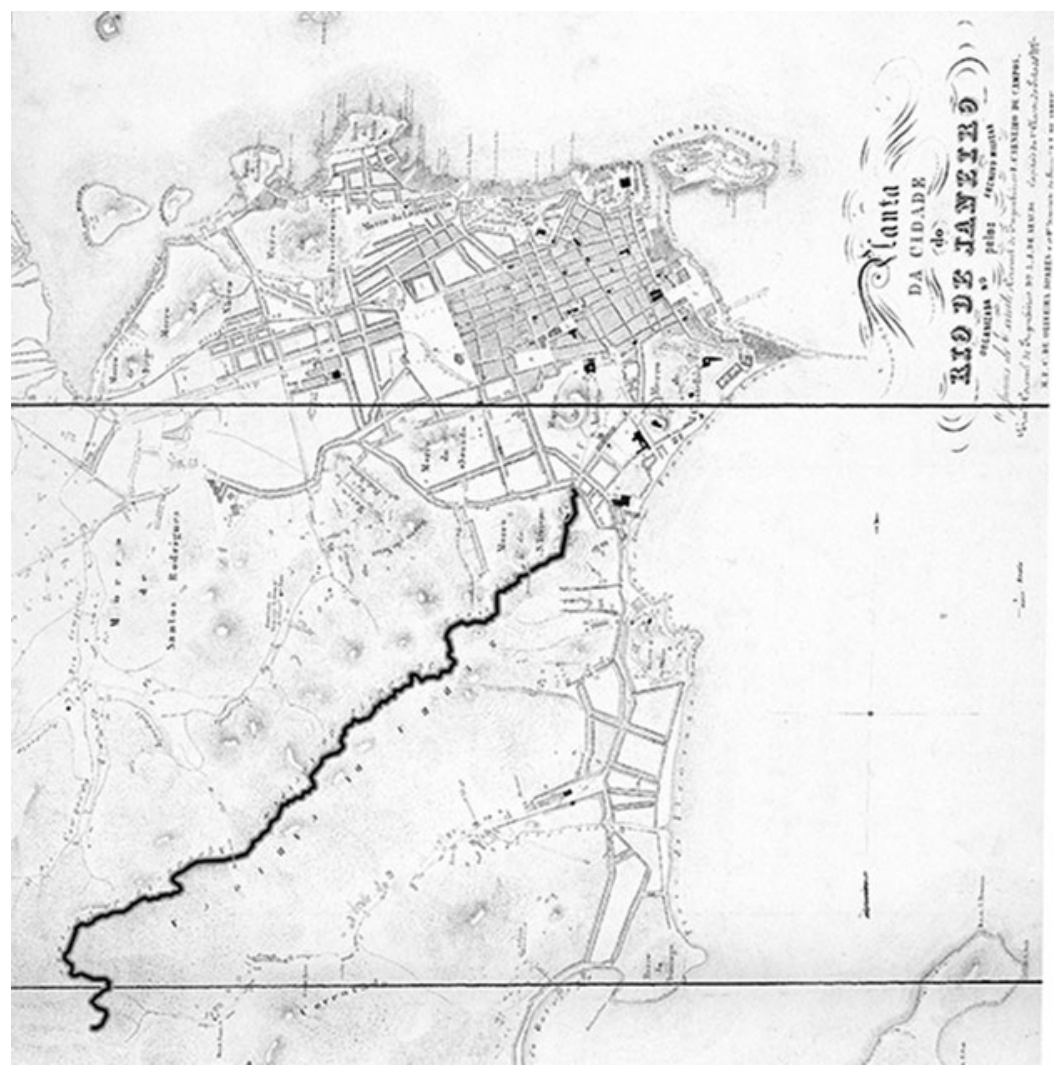

Figure 6. Traced segments of the Carioca Aqueduct, over georeferenced map of 1858

Source: Carneiro de Campos et al., Planta da Cidade do Rio de Janeiro, 1858. Geography and Map Division, Library of Congress, http://hdl.loc.gov/loc.gmd/g5404r.ct003652, available in imagineRio 1858.

rain. ${ }^{44}$ In the historical GIS (HGIS) we created a digital reconstruction of the path of the Carioca Aqueduct between Santa Teresa and the Mother of Waters by tracing the segments on the 1858 map (see Figure 6).

When we overlaid the segments onto a topographic layer in the HGIS, the aqueduct appeared to have little regard for the terrain. Moreover, when we compared several georeferenced historical maps in our HGIS, in order to capture details

\footnotetext{
${ }^{44}$ 'Georeferencing is the GIS process of adding spatial information to a map or image...By creating links on the historical maps to persistent locations also found in modern spatial datasets (e.g. street intersections), the GIS software situates the historical map image in the correct spatial scale, arrangement, and dimensions', see S.W. Kennedy, 'Lowering mortality: a spatial history of segregation, environments, and mortality transitions in New Orleans, 1880-1915', Rice University Ph.D. dissertation, 2018, https://scholarship.rice.edu/handle/1911/105865, fn. 24, accessed 24 Jun. 2020. Georeferencing allowed us to digitize historical spatial features, such as the Carioca Aqueduct, from the original maps. The aqueduct's path through the mountainous regions made it difficult to map in the eighteenth and nineteenth centuries. As will be shown below, the drawing of the aqueduct must be done against modern basemaps in consultation with direct observation, in order to obtain an accurate path.
} 
about the Carioca Aqueduct from different moments in time, we encountered an accuracy problem. The route of the aqueduct as traced from the 1858 map did not always match the route of the aqueduct on other georeferenced historical maps.

We looked to other sources to inform a better digital reconstruction of the aqueduct's path. Street names can contain useful historical information, even as names change over time. A city map from 1923 has a detailed list of street names, including the Rua do Aqueducto (Aqueduct Street) which runs from the Reservatório da Carioca (Carioca Reservoir) - on the site of the Mother of Waters - down through the Tijuca Forest into the neighbourhood of Santa Teresa. ${ }^{45}$ A city map a decade later no longer has a Rua do Aqueduto, but a new name: Rua Almirante Alexandrino (Admiral Alexandrino Street), which is the modern street name. ${ }^{46}$ Figure 7 shows two historical maps, both georeferenced, and both set at the same location. The Rua do Aqueduto on the 1923 map appears in the same place as the Rua Almirante Alexandrino on the 1932 map. Only the name has changed. Thus, the aqueduct must have run along, or very near, the modern street named Rua Almirante Alexandrino.

The cartographic inaccuracies in the 1858 map became even more apparent when we first compared the aqueduct segments to a modern street map. The segments traced from the 1858 historical map did not consistently match the Rua Almirante Alexandrino. Because the aqueduct descended through the hills, the nineteenth-century cartographers had difficulties accurately representing the threedimensional route of the aqueduct on a two-dimensional map. Although we attempted to derive the aqueduct's real-world location from an otherwise accurate historical map, the map's imprecision in the hills limited the viability of this approach.

In the late nineteenth century, when the new sources of water came into the city, old sources once carried in the Carioca Aqueduct were re-piped and the monumental water bridge ceased to deliver water into the city centre. Subsequently, the double arched arcade was repurposed as a tram line. This line commenced in the city and reached the Santa Teresa neighbourhood via the water bridge. From Santa Teresa, the tram line continued up into the Tijuca Forest, following the aqueduct. This can be seen in many late nineteenth- and early twentieth-century photographs that show the raised walls and sloped roof of the aqueduct, much as Ewbank drew them, as well as tram tracks. In Figure 8, the tram tracks are clearly visible next to the aqueduct, in the neighbourhood known as 'Sylvestre' (Silvestre).

The inaccuracies in the 1858 map and our uncertainty about the aqueduct's route suggested that a field survey, which we conducted in May 2014, might answer several questions. We began in Santa Teresa, above the double arched water bridge and followed the tram tracks along Rua Almirante Alexandrino as far into the

\footnotetext{
${ }^{45}$ C.Q. Bacellar, Planta Geral da Cidade do Rio de Janeiro (Rio de Janeiro, 1923), available through the Biblioteca Nacional Digital Brasil, http://acervo.bndigital.bn.br/sophia/index.asp?codigo_sophia=13614, accessed 24 Jun. 2020, also available georeferenced in imagineRio 1923, https://imaginerio.org, accessed 24 Jun. 2020.

${ }^{46}$ A.D. Ribeiro, Planta informativa do cento da cidade do Rio de Janeiro: especialmente organizada para o Guia Briguiet (Rio de Janeiro, 1932), available through the Biblioteca Nacional Digital Brasil, http://acervo. bndigital.bn.br/sophia/index.asp? codigo_sophia $=13544$ also available georeferenced in imagineRio 1932, https://imaginerio.org, accessed 24 Jun. 2020.
} 

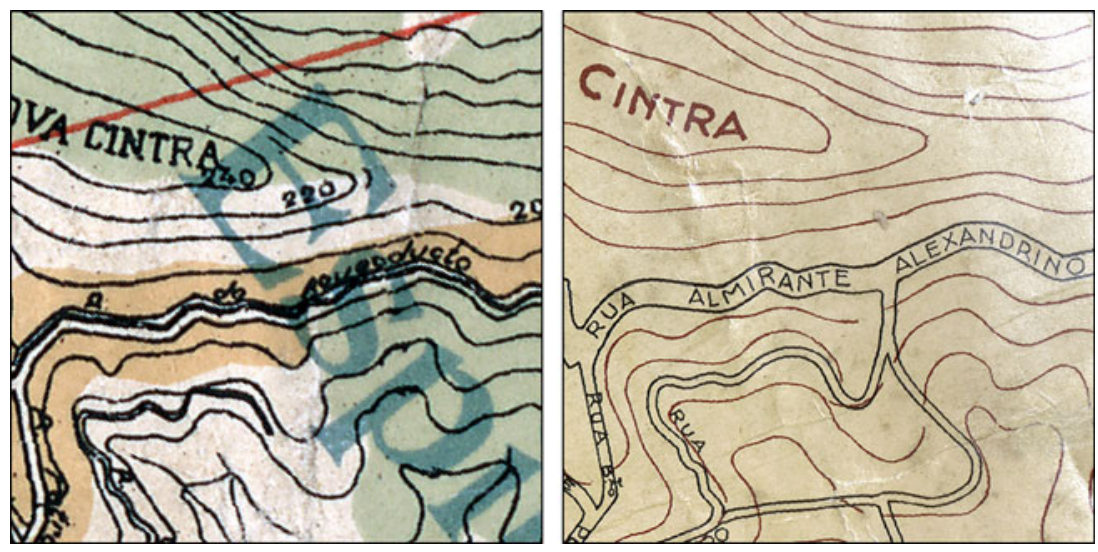

Figure 7. Changes in street names: Rua do Aqueduto (1923) - to Rua Almirante Alexandrino (1932) Sources: Left: detail from Bacellar, Planta Geral da Cidade do Rio de Janeiro, Biblioteca Nacional Digital Brasil, http:// acervo.bndigital.bn.br/sophia/index.asp?codigo_sophia=13614, available in imagineRio 1923. Right: detail from Ribeiro, Planta informativa do centro da cidade do Rio de Janeiro: especialmente organizada para o Guia Briguiet, 1932, Biblioteca Nacional, Brasil, http://acervo.bndigital.bn.br/sophia/index.asp?codigo_sophia=13544, available in imagineRio 1932.

Tijuca Forest as possible. The tram lines we followed stopped at the end of the Rua Almirante Alexandrino, very close to where the modern Corcovado train track crosses the Estrada das Paineiras. There, we immediately identified many features of the old aqueduct. A modern blue historical marker clearly identified the Casa Mãe d'Água (House of the Mother of Waters). The marker was attached to the front wall of a nineteenth-century house-like structure that sat next to three massive water tanks, which were constructed in $1865 .{ }^{47}$ This is the Reservatório da Carioca (Carioca Reservoir), which appears in the 1923 city map, but is no longer functional today. When Ewbank reached this location in 1846, the Reservatório da Carioca was still decades away from being built, yet already the area was critical to the city's water infrastructure. He sketched the waterworks structure at this location, and his close attention to detail is evidenced by the inclusion of a historical plaque attached to the side of the building (see Figure 4). Ewbank detailed the location in his writings, and he provided an English translation of the text on the plaque, which carries the date of 1744 . In our 2014 field survey, we found a similar stone structure near the Reservatório da Carioca that we suspected was part of the waterworks. Attached to the side of the structure was an old stone plaque, but the text was nearly illegible due to recent graffiti. After close inspection, we compared the text of the plaque to the text recorded by Ewbank in 1846, and they matched. Figure 9 shows the plaque on the side of a structure as we saw it in 2014. The street, Rua Almirante Alexandrino, appears in front of the stone structure, and the tram tracks are clearly visible. The inscription is transcribed in Figure 9, top right, and Ewbank's description of it appears in Figure 9, bottom

\footnotetext{
${ }^{47}$ Caixa de Mãe D'água e Reservatório Carioca ou Caixas do Carioca', Inventário de Identificação dos Reservatórios da CEDAE, INEPAC, Secretaria de Estado de Cultura, RJ, http://www.inepac.rj.gov.br/application/assets/img/site/4_ficha_carioca.pdf, accessed 24 Jun. 2020.
} 


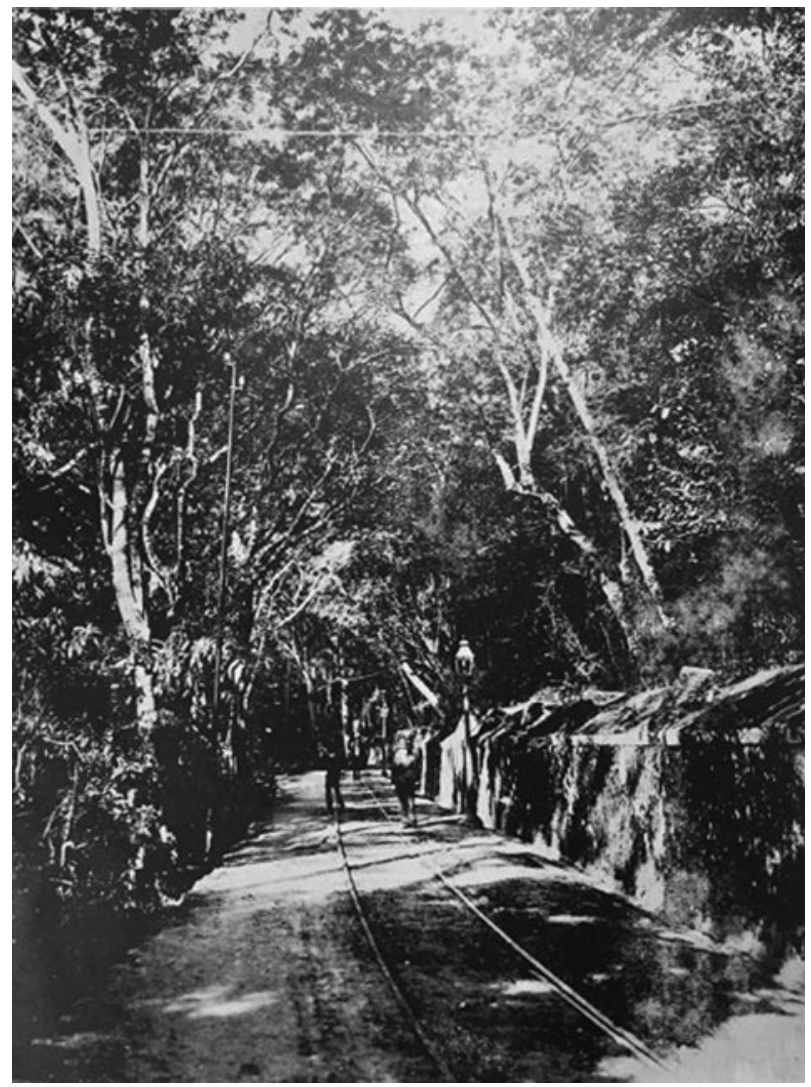

Figure 8. Anon., 'Sylvestre' with tram lines and aqueduct, right Source: F. da Rosa, Rio de Janeiro (Rio de Janeiro, 1905), 127.

right. Based on this discovery, we were confident that this was the same eighteenthcentury structure and location visited by Ewbank in 1846. This provided a groundtruthed geographic point of reference for the aqueduct. ${ }^{48}$

From Mãe d'Água, we turned to follow Rua Almirante Alexandrino downhill, always alongside the tram track. We used a GPS (Global Positioning System) receiver to record the route of our survey, and we captured geotagged images with a camera. A low wall edged the street on the precipice side. The wall had distinct segments that joined each other at angles, some obtuse, and a few nearing right angles, just as described by Ewbank. We identified other features of the aqueduct, such as support arches and locations where springs joined the descent (Figure 10). Once we arrived in the more populous neighbourhood of Santa Teresa, it was no longer possible to determine the aqueduct's historical route due

\footnotetext{
${ }^{48}$ On a later visit, we discovered that the plaque has since been cleaned. There are multiple Google StreetView images of the plaque; see the approximately 10 different captures between 2010 and 2016: www.google.com/ maps/@-22.9451869,-43.2083479,3a,77.3y,346.02h,93.36t/data=!3m7!1e1!3m5!1sSXCtV6UO6lqKFua_EUzatg! 2e0!5s20141101T000000!7i13312!8i6656, accessed 24 Jun. 2020.
} 


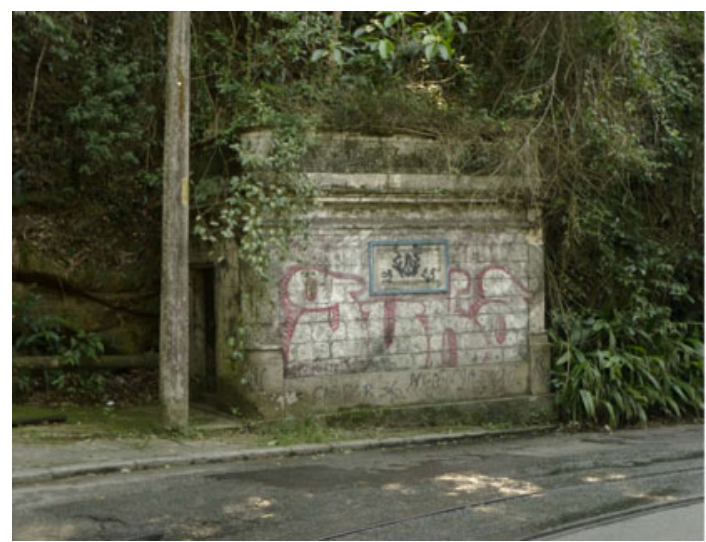

REYNANDO EL REY D. JOÃO

V N.S. E SENDO G. ${ }^{R}$ E CP. ." G. ${ }^{\perp}$ DES

TAS CAP's E DAS M"s G'S GOMES

$\mathrm{FR}^{\varepsilon}$. DE ANDR. ${ }^{\wedge}$ DO SEO CON ${ }^{\mathrm{C}}$ SARG.

MAYOR DE B.` DOS SEOS EXER. ${ }^{\text {TO }}$ ANO 1744

"At the junction of the conduit with the reservoir there is a corroded marble tablet let into the end wall of the latter. The inscription is in old and abbreviated Portuguese. With some difficulty we made out the letters : they are to this effect :

"Under our Lord King John V., Gomes Freire de Andrade, Governor and Captain General, and

Councilor to the King, 1744."

Figure 9. Eighteenth-century plaque and its texts, Mãe d'Agua Sources: Photograph by the authors, 2014 (left); transcription of plaque (top right); Ewbank's comment, Life in Brazil, 415 (bottom right).

to centuries of active construction in the area. Today, the double arched arcade that once carried water from the Morro de Santa Teresa to the Morro de Santo Antonio only serves as a tram line for tourists, and the modern fountain in the Largo da Carioca is fed from other sources.

The process of accurately reconstructing the route of the Carioca Aqueduct in our HGIS required us to rethink ways to glean geographic information from the HGIS. Even as our field survey seemed to confirm that the aqueduct descended in segments, as described by Ewbank and as recorded on the 1858 military map, the spatial relationship of the segments traced from the georeferenced 1858 map proved inaccurate. We re-georeferenced the 1858 map using control points, not for the city centre but for the region through which we believed the aqueduct ran. On the re-georeferenced map, the segments of the aqueduct more closely followed the Rua Almirante Alexandrino, although it was not a perfect fit. Based on our field survey findings, we felt confident that the aqueduct followed the Rua Almirante Alexandrino. Thus, we chose to use modern aerial imagery to trace the aqueduct's path along Rua Almirante Alexandrino into the HGIS. This approach prioritizes the locational accuracy of the aqueduct at elevation over the details of each individual section (Figure 11).

Subsequently, we created a 3D model to visualize the long journey of water in the aqueduct, beginning high up in the Tijuca Forest and flowing down into the city centre of Rio. ${ }^{49}$ We selected a later version of the 1858 historical map, the Lammert 1867 map of Rio, because of its use of colour. On the Lammert map, red symbolizes the densely built blocks of the city centre, thus giving a good idea

\footnotetext{
${ }^{49}$ We used ArcGIS Pro (ESRI, 2019) to build a historical 3D model of Rio de Janeiro. We combined modern topographical data and contour lines from historical maps to approximate the terrain surrounding historical Rio. We then draped the georeferenced 1867 historical map onto the 3D elevation model.
} 

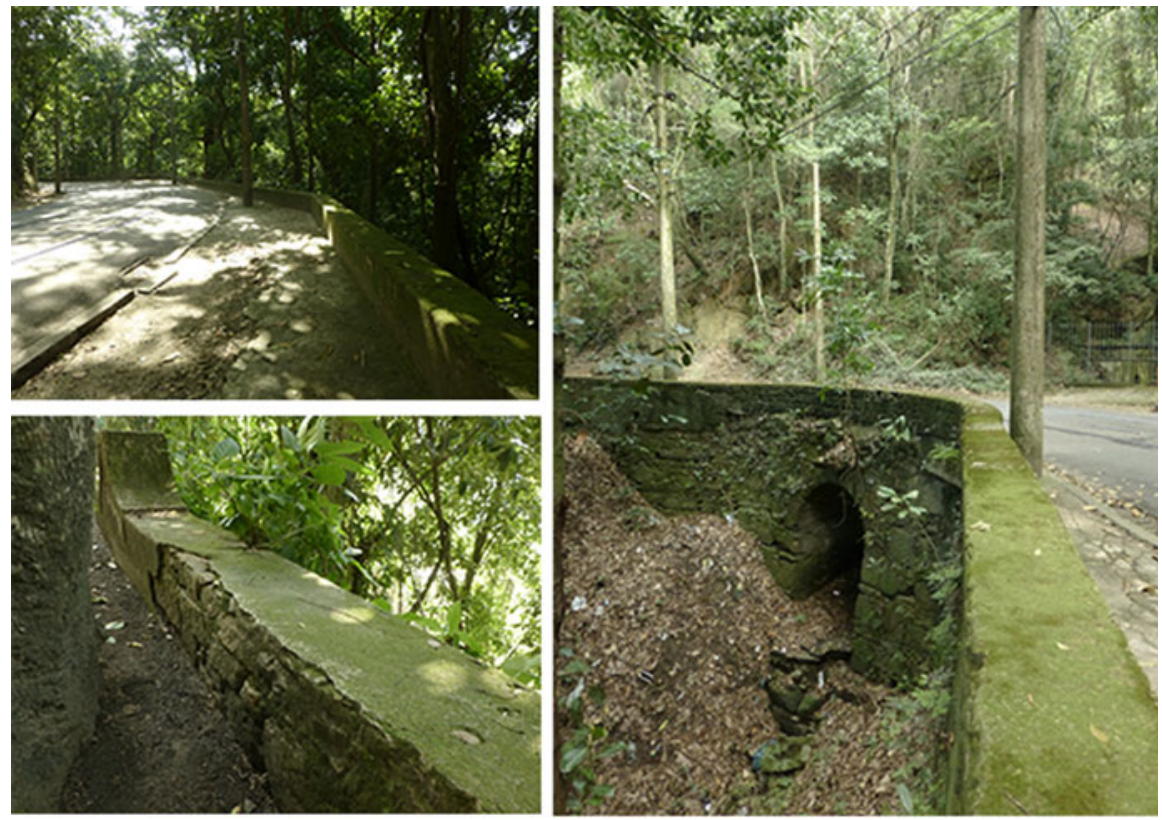

Figure 10. Remains of the Carioca Aqueduct Source: Photographs by the authors, 2014.

of the built environment. The forest and surrounding countryside is rendered in green. ${ }^{50}$ In virtually every respect, the 1867 map appears to be a direct copy of the 1858 map (or drawn from the same prototype). Figure 12 shows the two georeferenced maps side by side and presented at the same scale, making clear their similarities. The Carioca Aqueduct is highlighted on both with the digitized layer that we created by tracing the Rua Almirante Alexandrino.

When the 1867 historical map is draped over the contour lines in our HGIS, the visual image of the city is striking on several fronts (see Figure 13). First, the route of the aqueduct (symbolized as a white line) clearly demonstrates the underlying principle of the technology: gravity moves water. The water system allowed Rio to use the mountains to capture water and deliver it to the city. The water's origins, high in the forest, below the Corcovado Peak, is well captured. The distance the water travels through the aqueduct, as well as the way that it makes its way around hills, is also visible. Our 3D model also suggests both the strength and weakness of Rio's water delivery system at the middle of the nineteenth century. Because the source of the water was high above the city, it was difficult for contaminants, such as bacteria from human waste, to enter the water supply. Yet the aqueduct was itself vulnerable to breaks, sabotage, illegal extraction and overflows from heavy rainfall.

\footnotetext{
${ }^{50}$ E. and H. Laemmert, Nova Planta da Cidade do Rio de Janeiro (Rio de Janeiro, 1867), available through the Geography and Map Division, Library of Congress, www.loc.gov/resource/g5404r.br000055/, accessed 24 Jun. 2020, also available georeferenced in imagineRio 1867, https://imaginerio.org, accessed 24 Jun. 2020.
} 


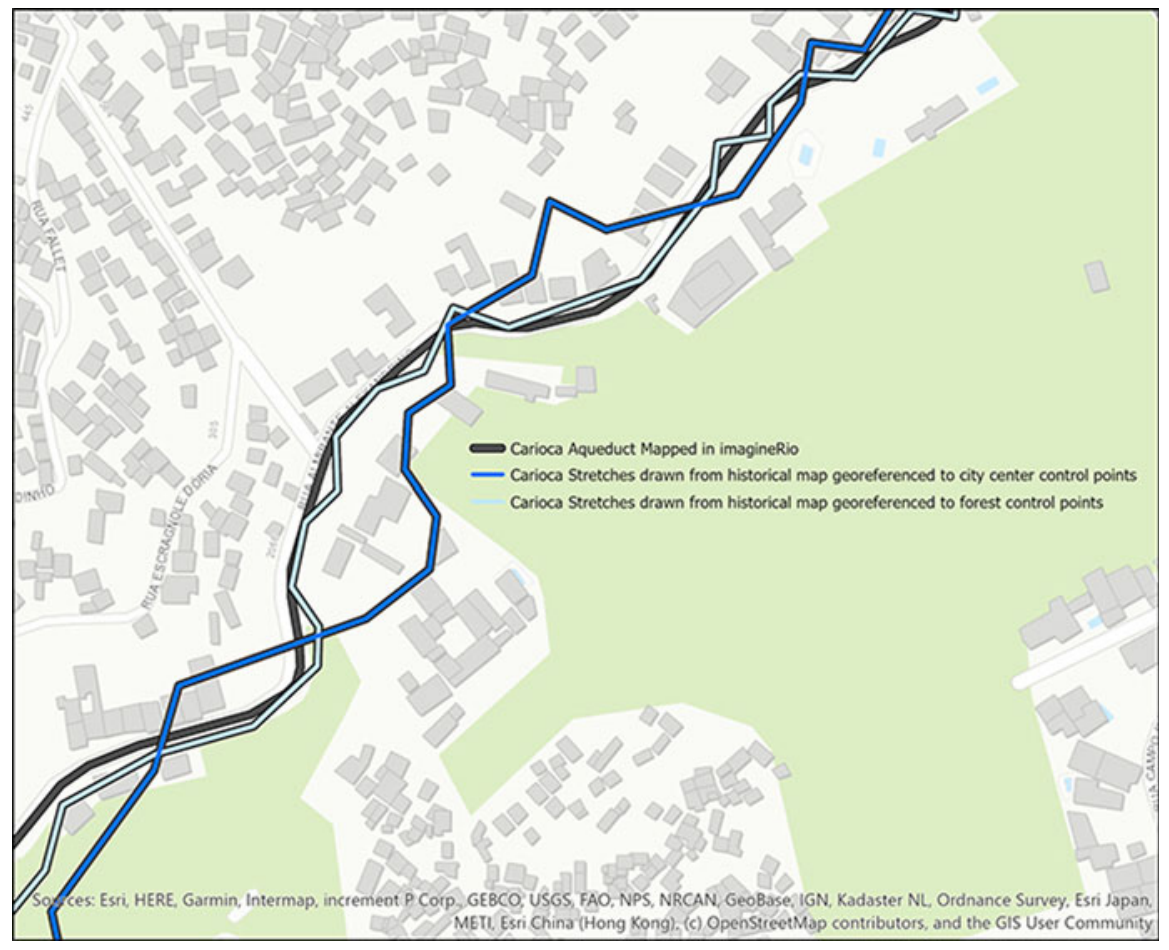

Figure 11. Segments of the Carioca Aqueduct from two differently georeferenced versions of same map (1858) and final placement of the aqueduct along Rua Almirante Alexandrino Source: Map created in ArcGIS using data from imagineRio.

\section{Water delivery in the city}

The 3D model (Figure 13) visualizes the city's use of topography to transport fresh water into Rio, yet this was only part of the water infrastructure. The second system, powered not by gravity but by human labour, distributed water once it reached the city. As Jorun Poettering argues for colonial Rio, 'slaves were of such great importance for the daily provisioning of water to the residents [that] it was impossible to banish them from the public image of the city'. Poettering notes that a sentinel at the fountain ensured law and order but underscored that the fountains were 'contrary to the visions of a public space as conceived by the white elites. ${ }^{51}$ Many visitors to Rio in the early nineteenth century did comment on the water carriers in their accounts of the city, and in their street scenes, artists frequently captured the ubiquity of water carriers.

According to the calculations of the Public Works Office, which Ewbank obtained and later published, the Carioca Aqueduct supplied four major fountains in Rio (see Table 2). It should be noted that other city fountains, such as that in the

\footnotetext{
${ }^{51}$ J. Poettering, 'Water and the struggle for public space: social negotiations in the usage of colonial Rio de Janeiro's waterworks', Brasiliana-Journal for Brazilian Studies, 5 (2017), 154-70; quotations from 167.
} 


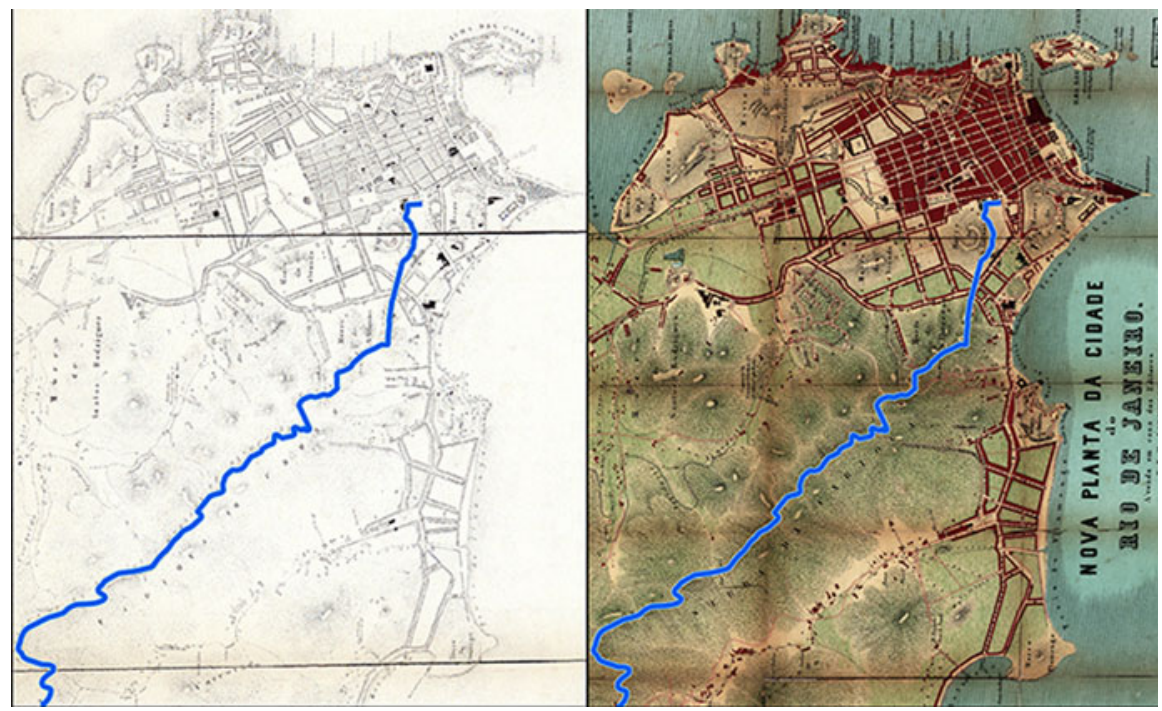

Figure 12. The 1858 and 1867 maps of Rio (with Carioca Aqueduct highlighted) Sources: Left: Carneiro de Campos et al., Planta da Cidade do Rio de Janeiro, 1858. Geography and Map Division, Library of Congress, http://hdl.loc.gov/loc.gmd/g5404r.ct003652. Right: Laemmert, Nova Planta da Cidade do Rio de Janeiro, 1867. Geography and Map Division, Library of Congress, www.loc.gov/resource/g5404r.br000055/.

Campo de Santana or the fountain in front of the Santa Rita church were supplied by the Maracanã Aqueduct, which Ewbank did not study.

Ewbank's descriptions of several fountains he visited in Rio shed light on these central nodes in the provisioning infrastructure of the city. On the one hand, he found them 'eminently picturesque' and 'could not resist the temptation to sketch them' and for several days, he sought to draw them one by one. Only one image of a fountain appears in his book, and it shows the Santa Rita fountain. This fountain was one of the newest fountains in Rio, erected in 1839. Its location brought water much closer to the northern, poorer neighbourhoods of the city. Whether Ewbank sketched it himself is unclear; he mentions in his text only that 'a day view of this old structure [Santa Rita church] and the adjoining fountain is shown on page 312' (see Figure 14). The image shows the fountain in a small square, with the Santa Rita church behind it. On the other hand, Ewbank found the fountains crowded and busy, the spaces around them dominated by slaves, which he often described in pejorative ways. The scene of the Santa Rita fountain is thronged with slaves, each with their 'barril', which Ewbank elsewhere describes as 'universal' and 'omnipresent' and with which 'the head of every slave is familiar. ${ }^{52}$

The fountains flowed continuously, and water collection was a daily activity. Walking along Rua do Catete on a hot Sunday evening, Ewbank came to the fountain and found there 'an open spot on the right, in which stood a fountain vase, and

\footnotetext{
${ }^{52}$ Ewbank, Life in Brazil, 263, 208, 312, 359-60. On the opening of the Santa Rita fountain, see J. de Santa Rita, A água do Rio: do Carioca ao Guandu. A história do abastecimento de água da cidade do Rio de Janeiro (Rio de Janeiro, 2009), 81-2.
} 


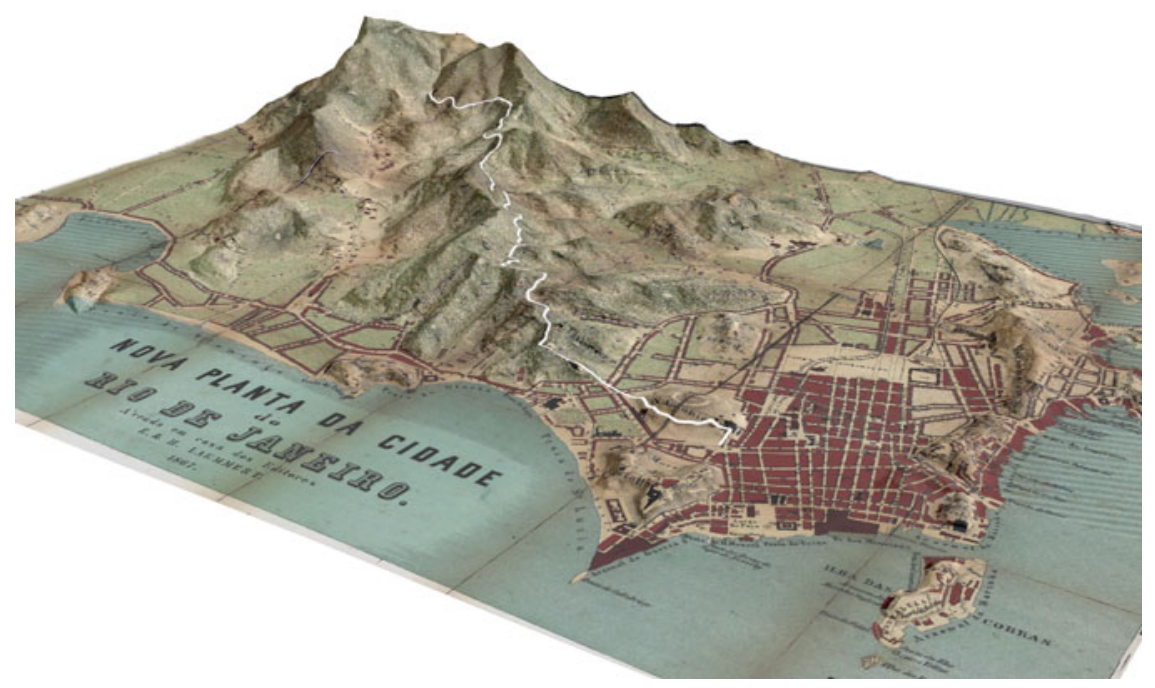

Figure 13. The course of the Carioca Aqueduct from the Corcovado to the city centre Sources: 3D model created in ArcGis with data from imagineRio. Historical map: Laemmert, Nova Planta da Cidade do Rio de Janeiro, 1867. Geography and Map Division, Library of Congress, www.loc.gov/resource/g5404r.br000055/.

at it negroes filling vessels, ${ }^{53}$ Thus, Sundays, considered to be days of rest, were not for the domestic servants, required to get water. On another hot Sunday, he again writes about slaves at the city's fountains filling their water vessels. Here, his racism is obvious, for Ewbank makes an analogy linking slaves to animals. Ewbank's words: 'On sultry mornings like this, the noisiest scenes are at the fountains. The gabbling crowds, pushing forward their "barils" [sic] to the spouts, remind one of litters of squealing porkers hustling each other in their eagerness for a breakfast.' At the fountain in the Campo de Santana, which was fed by the newer Marananã aqueduct, he again used an animal analogy, this time to birds, to convey his impression of the laundresses who worked there. 'From the surrounding mountain peaks they must appear like clamorous daws ${ }^{54}$ or restless magpies. How busy they all are, each in the centre of a ring of drying garments! ${ }^{55}$

The subsequent description of the fountain in the Campo de Santana provides details about how the public spaces around fountains were sites of work - both for launderers and water carriers. In describing it, Ewbank positions himself apart from the scene, as a spectator: 'Let us draw near. What a hubbub! A Hottentot fair can not surpass it. These two military policemen may prevent a lusty negro squeezing in before his turn and pushing aside the half-filled baril [sic] of a weak one, but they can not silence the oral clamor.' The references to Africa (Hottentot fair) and to the

\footnotetext{
${ }^{53}$ Ewbank, Life in Brazil, 59.

${ }^{54} \mathrm{~A}$ daw is a small crow, also known as a Jackdaw, 'daw, n.', OED Online November 2019, Oxford University Press, $\quad$ www-oed-com.ezproxy.rice.edu/view/Entry/47499?rskey=MYqg7q\&result=1\&isAdvanced=false\#eid, accessed 24 Jun. 2020.

${ }^{55}$ Ewbank, Life in Brazil, 199, 113.
} 
Table 2. Water delivered by the Carioca Aqueduct, c. 1846

\begin{tabular}{lrc}
\hline Fountains & Barrils per 24 hours & Gallons per minute \\
\hline Carioca & 37,420 & 182 \\
Marrecas & 1,800 & 8.75 \\
Moura & 600 & 3 \\
Palace Square & 6,840 & 33.25 \\
\hline
\end{tabular}

Note: The barril is estimated at 7 gallons.

Source: Ewbank, Life in Brazil, 430.

physicality of slave men (lusty negro) are reflective of his racial bias, but ever observant, Ewbank notes that the excess water from the fountain 'runs into two stone cisterns, thirty feet by fifteen, and keeps them knee-deep filled'. This is the place where women washed laundry, a dozen or more in each cistern at a time. Ewbank does have compassion for the laundresses, who, he notes 'have no saint assigned them, yet they deserve one, were it only to relieve them once a year from the washing-tub. ${ }^{56}$

By mid-century, a few small water companies sold water. They delivered water from mule-drawn carts that rumbled through the streets, although it is likely that these private businessmen also relied on slave labourers. Each water cart had to be licensed by the city council, and surviving record books reveal that there were multiple water services in each parish. ${ }^{57}$ The large water casks were filled at the public fountains, or from private sources of water, and pulled through the streets.

Ewbank described scenes that illustrated the fragile nature of water delivery in the city. A store on the street below the Santo Antonio monastery caught fire, and Ewbank reached the scene - alerted by the ringing of the bells in the monastery church - even before the fire engine, which arrived after being pulled down the street by two black men, whom we can assume were most likely enslaved, supervised by an officer. Ewbank called the machine, which 'consisted of an open copper cistern on wheels' with 'two pump cylinders, the pistons of which were connected to a lever, and worked for and aft by a man at each end', as identical to engines used in seventeenth-century Europe. The cistern had to be filled with water, and to accomplish this 'a water cart was brought up, and the contents drawn into buckets and poured into the cistern'. Then a small hose 'conveyed the water to the flames'. Yet the fire, which took two hours to put out, did little damage, due, according to Ewbank, to the 'comparative incombustibility of woods employed in building'. The use of pine joists was prohibited, and fire was rarely used, except for cooking. Few houses caught fire in Rio, he learned, making the fire engine that was no bigger than a 'little garden pump' effective enough. On the same day, and on the same street, Ewbank passed a water carrier, an elderly slave woman. He described her as 'a short, spare, and feeble old woman, creeping along the pavement with a baril [sic] of water on her head. An iron collar grasped her shriveled throat, and from its prong a chain ran up and was secured to the handle of the vessel by a padlock - about as cruel a sight as I have seen yet.' In his neighbourhood lived a

\footnotetext{
${ }^{56}$ Ibid., 114-15.

${ }^{57}$ Abastecimento d'água, AGCRJ.
} 


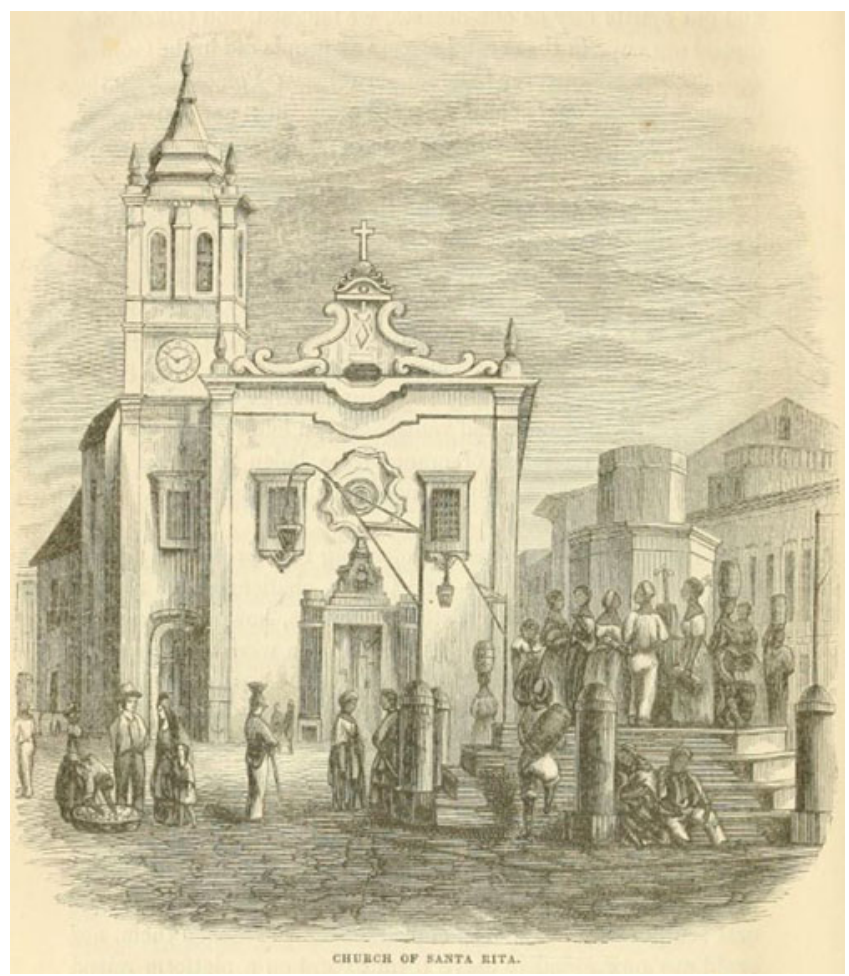

Figure 14. The Santa Rita fountain

Source: 'Church of Santa Rita', in Ewbank, Life in Brazil, 312.

slaveowner with 'the reputation of being unusually cruel to his slaves'. Ewbank watched the man's enslaved water carriers from his window: one goes 'for water three or four times a day, in an iron collar, with an upright prong at one ear, and a shorter one under the other. ${ }^{58}$ The imagery of these scenes provides both a literal and figurative view of the historical connection between slavery and water in Rio and the brutality of the daily labour regimes on enslaved bodies as they navigated the paths between the slaveholder's house and the fountains of the city. ${ }^{59}$

Ewbank understood the vulnerability generated by the city's heavy reliance on the aqueduct, writing, '[t]here are no reservoirs in case of drought or damage to the works, so that when the supply is interrupted in the mountains it ceases in the city'. Still, he believed the supply of water for the city of Rio was adequate in 1846, writing 'nature supplies this necessary of life in abundance' and that 'no city on earth is more favored in this respect than Rio' ${ }^{60}$ Ironically, Ewbank overlooked the threat that slave rebellion or work stoppage could pose to water delivery in the

\footnotetext{
${ }^{58}$ Ewbank, Life in Brazil, 430, 77.

${ }^{59}$ Ibid., 280-1.

${ }^{60}$ Ibid., 430.
} 
city. Because he focused on the potential for technical failure, Ewbank failed to consider the vulnerable aspects of the human element of Rio's water infrastructure. At mid-century, water still came to only a few public fountains, and it still had to be carried to residences. Very few homes had piped water; the monasteries and convents, located on hills, had their own wells. Although this would seem to mark Rio as a 'backwards' city, as many travellers saw it, Rio's public water was excellent and rarely contaminated, unlike other cities in the nineteenth century. The Carioca Aqueduct delivered clean water, except during heavy rains or droughts, which kept Rio free from the outbreaks of cholera that devastated other cities at the time. ${ }^{61}$ The fountains ran continuously, and their overflow was channelled through drains to the Guanabara Bay. Similarly, the overflow from open-air laundries drained down streets to the Bay. Human waste was carried directly to the beach by domestic servants, and therefore water was not used to flush away faeces. ${ }^{62}$

Accounts of travellers and historical maps georeferenced in a HGIS allow the water infrastructure in mid-nineteenth-century Rio de Janeiro to be understood as a system that relied on engineered built structures (aqueducts and fountains) and human labour (water carriers). The engineering of the aqueduct in the eighteenth century, and its maintenance in the nineteenth, did deliver clean water to the city. However, the last phase of water delivery required thousands of water carriers - in the majority slaves - whose bodies did the heavy labour of carrying water every day. Although traveller accounts are laced with racial bias, they do reveal this fundamental tension in Rio's water infrastructure. Ewbank, for example, stated that 'nature supplies this necessary of life [i.e. water] in abundance, and would, if permitted, deliver it freely at the door of every dwelling, and raise it into every garret'. Yet instead, even as he praised the Carioca Aqueduct, as 'one of the most interesting structures through which life's liquid ever ran', he recognized that the city had chosen to rely on slaves. 'Water', he wrote, 'is drawn down in open gutters [i.e. the aqueduct] to the lowest streets, and thence borne upward, day and night, to the highest, by thousands of slaves at an annual cost little exceeding that at which an ever-present stream in every house might be permanently attained. ${ }^{63}$

Adèle Toussaint-Samson described the water brought by Carioca Aqueduct as 'pure and sparkling' and remarked that it had a quality of which 'Europeans can

\footnotetext{
${ }^{61}$ Sidney Chalhoub writes that all of Brazil was free from the epidemics of cholera and yellow fever that attacked other countries in the first half of the nineteenth century. This was to change after 1850: see Cidade Febril: Cortiços e epidemias na corte imperial (São Paulo, 1996), 60. Adèle Toussaint-Samson writes vividly about yellow fever in 1849, which she and her husband both contracted soon after arriving in Rio; see $A$ Parisian in Brazil, 55-8.

${ }^{62}$ Ewbank writes, 'Here are no sewers nor sinks - no privies - no, not even where spacious yards and gardens are annexed to dwellings. The use of close-stools is universal even in the rural suburbs! Born on the heads of slaves, they are emptied into certain parts of the Bay every night, so that walking in the streets after 10P.M. is often neither safe nor pleasant. In this matter, Rio is what Lisbon is, and what Edinburgh used to be.' Life in Brazil, 88. A water-based sewage system was proposed in the 1860s, and the famous Gotto map of Rio was drawn for the intention of laying sewer lines. Thus, by the late 1860s, many houses in the city had piped water, making it possible to flush human waste through the proposed sewers. See E. Gotto, Plan of the City of Rio de Janeiro, Brazil (London,1866), available through Biblioteca Nacional Digital Brasil, http://acervo.bndigital.bn.br/sophia/index.asp?codigo_sophia=21957, accessed 24 Jun. 2020, also available georeferenced in imagineRio 1871, https://imaginerio.org, accessed 24 Jun. 2020.

${ }^{63}$ Ewbank, Life in Brazil, 409, 430, 77.
} 
have no idea', while Thomas Ewbank thought 'no city on earth is more favored' with respect to its water than Rio de Janeiro. The Carioca Aqueduct, an engineering marvel that drew so much attention from visitors, ultimately fed a highly exploitative human delivery system. Good water in Rio came paired with slavery. Even after the abolition of the transatlantic slave trade in 1850, slaves would continue to deliver water in the city. Gradually during the second half of the nineteenth century, piped water would be introduced, and new aqueducts would bring more water to the city. Even following the abolition of slavery in 1888 , fountains and spouts continued to supply many residents with their only access to water. When the city grew rapidly in the twentieth century, many informal communities had no easy access to water. The struggle for equitable water distribution remained, and continues to be, a challenge for Rio de Janeiro.

Cite this article: Metcalf AC, Smith SM, Kennedy SW (2022). 'A mere gutter!' The Carioca Aqueduct and water delivery in mid-nineteenth-century Rio de Janeiro. Urban History 49, 61-87. https://doi.org/10.1017/ S096392682000084X 